\title{
Qualified Animal Model Use Indicator
}

National Cancer Institute

\section{Source}

National Cancer Institute. Qualified Animal Model Use Indicator. NCI Thesaurus. Code C158367.

An indication as to whether the study was performed using a qualified animal model. 